\title{
Les Seuils de la Foi, Entrer dans la foi avec la Bible. Jalons pour une catéchèse d'adultes. Institut international Foi Art et Catéchèse, Seconde édition révisée, Parole et Silence, Paris 2009
}

Wydawnictwo Parole et Silence $w$ latach 2009-2013 opublikowało trzy źródłowe pozycje prezentujące założenia teoretyczne i praktyczne francuskiej koncepcji biblijnej katechezy dorosłych Mess'AJE. Kolekcja pod wspólnym tytułem Les Seuils de la Foi przedstawia główną ideę tej katechezy w wymiarze biblijnym, teologiczno-filozoficznym i pedagogicznym. Wiodącą pozycją wśród nich jest publikacja autorstwa twórcy powyższej koncepcji, profesora egzegety i historyka religii Jacquesa Bernarda zatytułowana Les fondements bibliques wydana w roku 2009. Kolejną zaś jest książka współtwórcy koncepcji katechezy Mess'AJE, nieżyjącego już wykładowcy Uniwersytetu Katolickiego w Lille Jean-Marie Beaurent, zatytułowana Ressources théologiques et philosophiques, wydana w roku 2013. Prezentację tegoż tryptyku rozpoczynamy od książki pod tytułem Entrer dans la Foi avec la Bible, której redaktorem jest Catherine Le Peltier, długoletni nauczyciel pedagogii czterech progów wiary w Międzynarodowym Instytucie IiFAC przy Uniwersytecie Katolickim w Lille.

Prezentowana książka jest efektem ponad 20-letniego doświadczenia ekipy nauczycieli akademickich torujących drogę oryginalnej koncepcji katechezy dorosłych realizowanej w wielu krajach świata. Wśród jej autorów znaleźli się więc Jacques Bernard, twórca teorii pedagogii czterech progów wiary i katechezy Mess'AJE oraz jego współpracownicy: teolog Jean-Marie Beaurent - kapłan diecezji Cambrai, Edith 
Herbeau - nauczyciel akademicki w Instytucie, Jean Luc Garin - wykładowca Seminarium w Lille, oraz asystenci techniczni i artystyczni: Jean-Noël Michalik oraz Emilie Delepoulle.

Praca zbiorowa, o której mówimy zawiera rozdział wstępny ukazujący Biblię jako drogę wiary, pozostającą w dialogu z religiami „naturalnymi", a także księgę redagowaną w czasie, będącą jednocześnie nośnikiem Bożego Słowa. Pozostałe cztery rozdziały odpowiadają tematycznie kolejnym progom wiary, zatytułowanym: Wyjście, Wygnanie, Jezus, Kościót. To na tej drodze czytelnik, a jeszcze bardziej uczestnik Sprawozdania katechez prowadzonych właściwą sobie metodą, może odkryć w Bii recenzje blii własną historię wiary. Katecheza Mess'AJE proponuje jej odczytywanie z wykorzystaniem przesłanek naukowych, a jednocześnie oferuje drogę rozwoju duchowego. Nie dziwi zatem fakt, że w każdym z rozdziałów znaleźć można zróżnicowany materiał umożliwiający realizację cyklicznych spotkań katechetycznych. Zgromadzone w nich teksty stanowią zatem: własną refleksję twórców, przytaczają dane archeologiczne, sięgają do źródeł literatury starożytnej, odwołują się do współczesnych przesłanek egzegetycznych, teologicznych, filozoficznych, zaczerpnięte są z Biblii, prowadzą do aktualizacji wiary biblijnej oraz wskazują na perykopy, które należy przestudiować w związku z podejmowanym tematem katechezy.

Książka jest bogato ilustrowana, bowiem obraz w katechezie Mess'AJE pełni wyjątkowo ważną rolę. Chodzi o to, by treści wiary odczytywać i smakować wieloma zmysłami. Dlatego obok słowa artykułowanego na różny sposób w katechezie proponuje się medytację obrazu, jak również percepcję muzyki integralnie powiązanych z biblijnym przekazem wiary. Wśród ilustracji znaleźć można opracowane na użytek katechezy schematy, mapy, zdjęcia, grafiki, reprodukcje dzieł sztuki, a w szczególności kadry obrazów Françoise Bürtz inspirowanych założeniami biblijnej katechezy Mess'AJE.

Wprowadzenie do wiary z Biblia spełnia funkcję przewodnika po treściach proponowanych w biblijnej katechezie dorosłych. Wytrawny znawca biblijnych treści katechetycznych znajdzie w nim kompendium wiedzy wykorzystywanej w katechezie Mess'AJE. Dla animatorów katechezy prowadzonej tą metodą jest rodzajem podręcznika metodycznego dostarczającego konkretnych materiałów do realizacji kolejnych tematów. Jako owoc pracy zespołowej, weryfikowanej w dydaktyce uniwersyteckiej przez dziesiątki lat, w kontakcie ze słuchaczami reprezentującymi różne kręgi kulturowe, jest niezwykle cenną pozycją w zakresie katechezy dorosłych, postulowanej przez Kościół jako podstawowa forma katechezy. 
$\mathrm{Z}$ racji na to, że ta forma katechezy od 25 lat toruje sobie drogę w Kościele rzymskokatolickim w Polsce lektura powyższej książki jest godna uwagi. Podjęte w Archidiecezji Białostockiej starania o jej tłumaczenie pozwala żywić nadzieję, że będzie ona dostępna także $\mathrm{w}$ wersji polskiej. Ważnym dopełnieniem lektury będzie sięgnięcie po dwie pozostałe pozycje, które dadzą czytelnikowi pełny obraz omawianej koncepcji katechezy. 